\title{
Uses of Scottish place-names as evidence in historical dictionaries
}

Historical dictionaries provide a wealth of information which can often be very significant for place-name research. An investigation of the range and meaning of a placename element is usually enhanced by the knowledge of the range and meaning of the equivalent lexical item. Conversely, place-name studies have an important contribution to make to historical lexicography. This is particularly true for the history of the Scots language, the earliest extant literary example of which dates from the late fourteenth century. However, toponymic material raises some difficult taxonomic questions for the lexicographer, not least because he or she must devise a method by which it may be decided whether a piece of evidence is treated as a word or as a name. This paper seeks to examine some of the lexicographical advantages which may be gained from a detailed consideration of place-name evidence in the context of the Germanic languages of the British Isles. Examples focus particularly on Scottish material, and have been taken from the corpus of Germanic place-name elements in southern Scotland which I have compiled, and from the Third Edition of the Oxford English Dictionary (OED3).

During the twentieth century, the toponymic corpus of England became established as a valuable resource for the early history of the English language. Many influential publications on English place-name vocabulary have been produced during the last eighty years by the English Place-Name Society, including reference works such as Smith (1956), a new edition of which is currently in progress at the University of Nottingham (Parsons \& Styles with Hough 1997, Parsons \& Styles 2000). More recently, Gelling and Cole (2001) has examined a wide range of topographical place-name elements, and many of the detailed studies by Hough (e.g. 1995, 1998) and Kitson (e.g. 1997, 1998) have revealed words and 
meanings which were previously unidentified. Collectively, these findings have made a substantial contribution to our understanding of the vocabulary of Old and Middle English.

Despite the ancient linguistic connections between the territories now known as England and Scotland, Scottish place-names have seldom been taken into consideration in studies of historical vocabulary, even though many Old and Middle English place-name elements have direct equivalents in Early and Middle Scots. One of the main reasons for this omission is that the Scottish Place-Name Survey is less advanced than its English counterpart, with much important material remaining unpublished. However, invaluable raw material can be found in the archives of the Scottish Place-Name Survey, and in Dixon (1947), Macdonald (1937) and Williamson (1942), three $\mathrm{PhD}$ theses which were written at the University of Edinburgh over fifty years ago. Of these, only Macdonald's work on West Lothian names was published in book form (1941).

Nevertheless, the value of Scottish place-name evidence has not been entirely overlooked. As Sir William Craigie pointed out in his introduction to the first volume of the Dictionary of the Older Scottish Tongue (DOST):

The continuous Scottish record begins only with Barbour's Brus in 1375, and the contemporary Legends of the Saints. Before that date the scanty evidence has mainly to be gleaned from the place-names and personal designations occurring in the Latin charters or other documents relating to the south-eastern counties, or from legal terms employed in a Latin context in the early laws. These sources have been carefully examined for this evidence, which enables the Scottish form of a considerable number of common words to be traced back to the $12^{\text {th }}$ or $13^{\text {th }} \mathrm{cc}$.

(DOST: I, vii.) 
Craigie is perhaps a little unjust in his reference to the "scanty" pre-literary evidence. A surprising quantity of material is available for analysis, and it can be used for much more than simply identifying older examples of common words. Significantly, in the later volumes of DOST, the contribution of place-name material receives more recognition and is given a much more thorough and detailed treatment. In the discussion of Middle Scots feld, felde "field" for example, it is noted that a number of place-names dating from the pre-literary Scots period contain this element, including Wytefeld (c. 1200), Westfeld (1294), Lyllochefylde (1293) and Prestfeld (1327) (DOST s.v. feld(e n.). ${ }^{1}$ Similarly, at the entry for hall "large and spacious building, esp. one which is the residence of a magnate", the dictionary records early uses of the word in the names Blachall (1329) and Halton (1345-50) (DOST s.v. hall n.). In the entry for fidlar "fiddler", the earliest evidence for the word is found in the place-name Fiddillariscroftis (1457), Fidlariscroft (1458), and the onomastic examples have been included in the entry as square-bracketed quotations at the beginning of the quotation paragraphs (DOST s.v. fidlar $\mathrm{n}$.).

A number of scholars have made a significant contribution to Scottish onomastics in recent years. W. F. H. Nicolaisen deserves special recognition, as he has used place-name evidence to examine a wide variety of linguistic issues from sound-change to 'onomastic dialects' (e.g. Nicolaisen 1976, 1993, 1995, 2001). Simon Taylor's work has also considered many aspects of Scottish onomastics, and recently addressed aspects of the relationship between place-names and lexicography at the $45^{\text {th }}$ Conference of the Scottish Medievalists which celebrated the completion of DOST (Taylor 2002). Other scholars including Carole Hough, Doreen Waugh, Barbara Crawford, Gillian-Fellows Jensen, and Ian Fraser have made a significant contribution to Scottish place-name studies. Consequently, the gap between Scottish and English place-name studies is gradually being bridged. A particularly relevant example of this is found in Hough's discussion of the Scottish place-name Bemersyde 
(Hough 1999). In literary sources the word that forms the first element of this name is attested with the meaning "trumpeter", but she has shown that it was also used in a transferred sense to denote a type of bird, specifically the bittern. This usage can be found both in English place-names derived from West Saxon bȳmere including Bemerton in Wiltshire and Bemersley in Staffordshire, and in the Scottish place-name Bemersyde in Berwickshire, derived from Anglian bēmere (Hough 1999).

There are many other Scottish place-names which similarly deserve to be considered for their contribution to our knowledge of the early lexicon of the British Isles. In my own research, I have compiled a corpus of the Germanic elements so far identified in the placenames of southern Scotland. From this body of material, it is possible to identify many examples of terminology recorded in place-names earlier than in literature, and terminology which is unattested or of low incidence in the literary corpus, for which the place-name evidence is often particularly significant.

For example, Macdonald notes that the name Priest Mill in West Lothian is first recorded in 1534 in the form Breistmyln(e), which represents the Scots compound breist-mill or breast-mill (Macdonald 1941: 47). This is the Scottish equivalent of English breast-mill, which Wright defines as "a water-mill in which the water goes in at the side or breast to turn the wheel" (EDD s.v. breast n. 5). In later spellings, the initial consonant is changed by folketymology, with the form Priestmyln being recorded from the later $16^{\text {th }}$ century (Macdonald 1941: 47). The word breist-mill is not recorded in either DOST or the Scottish National Dictionary (SND), and so the place-name evidence allows the identification of a previously unrecognised Scottish compound. According to the Oxford English Dictionary, the English form breast-mill is attested from 1674, and therefore a significant ante-dating for this word is preserved in the earliest historical form of the name Priest Mill, recorded a hundred and forty years earlier (OED s.v. breast n. 11). One slightly earlier example of the English compound 
is shown by the place-name Breast Mill Beck in Lancashire, recorded as Bristmylbeck in 1526 (Parsons \& Styles with Hough 1997: 22). Both of these ante-datings deserve to be mentioned in any detailed discussion of the compound breast-mill, and the locations of these places, in West Lothian and Lancashire, may also serve to emphasise the shared vocabulary of the south of Scotland and the north of England.

Scottish place-names can also be used to identify elements that are unattested or rarely attested in the literary corpus. The Ayrshire name Privick, which only survives in the name of Privick Mill, is recorded from the late $12^{\text {th }}$ century as Preueic (a.1177; Fraser 1874: II, 1), and later as Prevyk (1379; Stuart et al. 1878-1908: III, 31), Previck (1429; Nicolaisen 2001: 103), etc., is likely to contain the rarely attested Old English peru "pear tree" compounded with Old English wīc "(dependent) farm" (Scott 2000). ${ }^{2}$ Tarbolton in Ayrshire, first recorded as Torboultoun (a. 1177) appears to have been formed by the addition of Gaelic torr "hill" to an earlier name from Old English *boðl-tun "house-enclosure, house-farm" a compound which is only attested in place-names. ${ }^{3}$ The same Old English compound can be found in the lost East Lothian name Botheltun, as noted by Nicolaisen, who has also drawn attention to the Hedderwick place-names, in East Lothian and Angus, which contain the unattested Old English *hoeddre "heather" (Nicolaisen 2001: 100, 102). OE *rydding meaning "a clearing" is possible in the lost Dumfriesshire name Batemanridding (1275-1329) and $\mathrm{OE} *$ wincel meaning "nook, corner" is likely in Winchburgh, West Lothian, first recorded as Wincelburgh in the late $12^{\text {th }}$ century (Williamson 1942: 217; Macdonald 1941: 44). In cases such as these, the Scottish place-name evidence expands the known geographical and historical spread of these elements, and deserves to be recognised by any comprehensive account of the words themselves.

These examples also reveal one of the most difficult taxonomic issues which has to be addressed in any analysis of early Scottish Germanic material. If a Scottish place-name 
element is clearly related to an Anglian Old English word, and there is historical support for an early coinage date, then the Scottish context in which it is found should not be ignored. This may appear to be a statement of the obvious, but early Scottish place-name elements have often been labelled "Old English", and considered as early evidence for the English language, with no further consideration as to the information they may provide for the Scots language. While Nicolaisen $(1976,2001)$ includes chapters on onomastic source languages including Gaelic, Scandinavian and Cumbric, he does not include a chapter on Scots. Earlier commentators have frequently ignored Scots elements. Dixon interprets all the Middle and Modern Scots names with the element side as evidence for Old English element sìde "side, slope of a hill or bank", with no further regard to the meaning of side at any point during the Scots period (Dixon 1941: 136). In doing so, he has overlooked the development of the element, including for example its later use as a suffix in the sense "direction, district, region", attested from the late eighteenth century (SND s.v. side n. 4).

Similarly, place-names first recorded in the Middle Scots period have sometimes been regarded as evidence for Middle English. The element index to Macdonald's work includes an entry for Middle English noke "nook, corner of land" (1947: 135), even though all of the evidence presented there clearly relates to the Middle and Modern Scots element neuk which can mean "nook", "projection of land" and "outlying or remote place", and deserves both on formal and semantic grounds to be considered within its Scottish context. Williamson treats the early forms of the Berwickshire name Bastle as evidence for Middle English bastle "strong tower", even though the oldest recorded spelling Foulenbastell (1614) is clearly Middle Scots in date (Williamson 1942: 172). Bastle, in the sense "bastille, fortified tower; siege-tower" is attested in Scottish literary sources from the sixteenth until the early twentieth century (CSD s.v. bastile n.), and it is very likely that careful analysis of bastle as a placename element would serve to enhance our knowledge of the semantic range of the word. 
Certainly the context of the evidence should not be ignored. The onomastic applications of bastle in Scotland may also be quite different from those found south of the border, for as Williamson herself notes, "there are no cases of the use of this word as a place-name element in Northern England" (Williamson 1942: 172). Bastel "castle tower" is only recorded in English place-names in the form bastile in one lost Cheshire field name, the Bastile Room, recorded in 1537 (Parsons \& Styles with Hough 1997: 53). In cases such as this, it would be very unfortunate if Scottish onomastic material was not considered together with contemporary Scottish lexical material.

Part of this problem is caused by the common convention of presenting the evidence for each English place-name element under the headword which corresponds to that element's Old or Middle English etymon. This system is problematic in the case of English place-names coined in the early modern period or later, and is an inadequate vehicle for Scottish Germanic material. It has long been recognised that Scots words are often quite distinct from their English counterparts, in terms of many factors including semantic range, phonology and etymology, and place-name elements are no different in this respect. While it is often useful to consider English and Scottish evidence together, the superficial similarity of English and Scottish evidence can also be deceptive, and for the sake of this caveat, if not for other reasons, it is important to recognise the contribution of Scottish place-names to the history of Scots as well as English.

The history of lexis in contextual use is the topic of primary concern for the Third Edition of the Oxford English Dictionary (OED3), but onomastic material from many parts of the British Isles, and sometimes beyond, is being incorporated into the revised text where relevant. When a lexical item in OED3 is derived from a place-name, the place-name itself will not be etymologized, on the grounds that the main focus of the dictionary is lexical, not onomastic, and place-names and words cannot be assessed using identical criteria. Although 
semantically transparent names never become truly fossilised, and therefore still retain some lexical meaning, it is nevertheless necessary for compilers of dictionaries to attempt to draw as clear a line as possible between the lexicon and the onomasticon.

In OED3, if the accepted or supposed etymology of a place-name throws light on some aspect of the use of the relevant headword in contextual use, then the information which is significant to the use and development of the word may be given in discursive text. For example, in the following entry, the name of the town of Masham in North Yorkshire differs in pronunciation from the word Masham which designates a specific breed of sheep, and it is useful to refer to the etymology of the place-name in order to explain this difference:

\section{Masham, $n$.}

Brit. /'mas(ə)m/, /'ma S(ə)m/, U.S. /'mæ $\int ə \mathrm{~m} /[<$ Masham, the name of a town in North Yorkshire, England (freq. explained as < an Old English personal name + -ham: see HAM $\left.n .^{3}\right)$.

The pronunciation /'mas(ə) $\mathrm{m} /$ has traditionally been used by residents for the name of the town; /'ma $\int(\partial) \mathrm{m} /$ is prob. a spelling pronunciation.]

A breed of sheep produced by crossing Wensleydale or Teeswater rams with Blackface or Swaledale ewes; a sheep of this breed...

(OED3 s.v. Masham n.)

Place-name evidence which antedates lexical evidence is also being incorporated into etymological notes where appropriate, as in the entries for MATH n. ${ }^{1}$ and MEREING n., shown below. In the case of MATH n. ${ }^{1}$, much of the phonological evidence for the later development of the word indicates that the Old English form may have had a doublet form 
with a short vowel. However, the two Devonshire examples of the name Meeth show a reflex of the Old English form with a long vowel, and are therefore relevant to the word's history:

math, $n .^{1}$

Now arch. and Brit. regional...Forms: OE mæp, mæð, ME (in compounds) mad-, math-, mathe-, 15-16 mathe, 15- math, 17 meath. [Cognate with Old Frisian mèth (neuter), Old Saxon mād- (in the compound māddag mowing day; Middle Low German $m \bar{a} t$ (feminine)), Old High German -mād (in the compound $\bar{a} m \bar{a} d$ (neuter) aftermath; Middle High German māt (neuter/feminine), German Mahd (feminine); cf. also the weak feminine noun from the same base represented by Old High German $m \bar{a} d a$ (Middle High German māde) swathe), ult. < the Germanic base of MOW v. ${ }^{1}$ The quantity of the root vowel in Old English has conventionally been taken to be long on the evidence of the cognates cited above; however, the subsequent history of the word in English suggests that Old English $m \bar{x} p$ may have had a doublet form map with short vowel: cf. Dutch mad, mat (neuter) swathe, and also the possible parallel of two Germanic ablaut grades (one with long root vowel, the other with short) clearly shown by the cognates of the Verner's law variant MEAD n. ${ }^{2}$ Almost all of the phonological evidence for the word after the Old English period points to the reflex of Old English map (or to an otherwise unparalleled shortening); evidence for the reflex of Old English $m \bar{x} p$ occurs in a few place names, as Meda (1086), Meðe (1175; now Meeth, Devon), la Methe (1249; now Meethe, Devon), and in the 18th-cent. form meath reported in the works of William Ellis (see Soc. Pure Eng. Tract (1945) LXIV. 103).

Although attested as an element in compounds, the word is not found as a simplex in Middle English except in the place name Le Mathes in Cambridgeshire 
(1221; also as the second element of compound place names (e.g. Wetemathis (1302), now Wheatmath Field, Cambridgeshire)).]

I. Simple uses.

1. A mowing; the action or work of mowing; that which may be or has been mowed; the portion of a crop that has been mowed. See also AFTERMATH n., BEADMATH n., DAY MATH n., LATTERMATH n., UNDERMATH n.

In R. E. Zupko Dict. Eng. Weights \& Measures (1968) defined s.v. as in Herefordshire equal to approximately 1 acre..or to the amount of land that a man could mow in a day', but app. on the basis of an instance of day's math (see quot. 1820 s.v. DAY MATH n.)...

(OED3 s.v. math n. ${ }^{1}$ )

In the etymology of MEREING n., there is a discussion of some of the early forms of the name of Westmorland, as there is some possibility that the late thirteenth century form Westmering contains the same word. However, it is also possible that West-mering instead shows influence from the word mere, and because that is the explanation we have preferred, the quotation has not been included in the quotation paragraph:

mereing, $\mathrm{n} . .$.

Forms: 15, 19- mering, 15- mearing, 16 meeringe, 17-18 meering, 18- mereing; Sc. (chiefly north.) pre-17 mearin, mering, meryne, pre-17 17- mearing, 17 meering, merin, 18- (now rare) mearen, miren; Irish English 18- mearing, meerin, merin, 19- marin, mearin', mearn.

$\left[<\operatorname{MERE} v^{2}+-\mathrm{ING}^{1}\right.$.

App. unattested in Middle English, although cf. the following: 
c1275 (?a1200) LA3AMON Brut (Calig.) 4972 Nome him scupte pe king \& hehte pene stan West-mering [c1300 Otho Westenering]; a muchel dæl londes pe per lið abuten nom pe king to his hond \& hæhte hit West-merelinge lond.

The above quot. occurs in a passage on the naming of Westmorland; cf. Old English Westmōringa land, lit. 'the land of those living west of the (Yorkshire) moors' (cf. - $\mathrm{ING}^{3}$ ). The form West-mering perh. shows alteration of the second element of the Old English word after MERE n. ${ }^{2}$ (cf. MERESTONE n., and the following early forms of the place name Westmorland: Westmerland (1129-33), Westmerieland (1183), Westmeriland (1190), Westmereland (1237)), rather than an isolated early attestation of the present word.

The following occurrence of mǣring in Old English in a Kentish charter has also been taken by some as an early attestation of this word, but the word division of the MS. is misleading, and Haðemǣring, a place name based on a personal name $H(e)$ a ðumǣr $\left(\mathrm{cf} .-\mathrm{ING}^{3}\right)$, is a more likely reading:

OE Bounds (Sawyer 546) in W. de G. Birch Cartularium Saxonicum (1893) III. 36 Of suð tune andlang broces to haðe mæringe ðonne on suð healfe of haðe mæringe to stoccum.

The location app. corresponds to a field whose name is variously recorded in later documents as Helmering (1526), Hellmerings (1620), and Hemmings (19th cent.)...]

I. Simple uses.

1. a. A boundary; = MERE n. ${ }^{2}$ 1. Also fig. Now chiefly Irish English...

(OED3 s.v. mereing n.) 
Some Scottish place-name material has also been incorporated into revised entries. One example is the entry for MICKLE a., pron., n., and adv. At sense 1. a. it is noted that the adjectival sense "great or large in size, bulk or stature" was used at one time to designate a particular place or building, and that this usage is now only retained in place-names. In the etymological note, examples of this type of name are given from both Scotland and England, including Mickleover in Derbyshire, Meikle Black Law in Berwickshire and Muckle Flugga in Shetland:

mickle $a$. , pron., $n .$, and $a d v$.

Now regional (chiefly Sc. and Eng. regional (north.)) and $\operatorname{arch...}$

[Cognate with Middle Dutch mēkel, Old Saxon mikil (Middle Low German (rare) mēkel; the commoner michel is a borrowing from Middle High German), Old High German mihhil, mihhal, mihhel (Middle High German michel, early modern German michel), Old Icelandic mikill, mykill (masculine accusative mikinn, mykinn, neuter nominative and accusative mikit, mykit), Norn (Shetland) mege (neuter), Norwegian (Nynorsk) mykjen, Norwegian (Bokmål) meget (now only as adverb)...

...In present regional use mickle is the prevailing form in the north of England, and muckle in Scotland (although meikle is frequently met with as a place-name element); in Northern Ireland meckle (now rare or obsolete elsewhere) is common alongside mickle and muckle; an isolated 20th-cent. instance of muckle in New England is recorded by Dict. Amer. Regional Eng. s.v. The archaistic use in nonregional poetry is rare, and almost confined to the form mickle.

From early times sense 1a was used to designate a particular place, building, etc.; this use now survives only in place names, e.g. Michelmersh, Hants., Mickleover, Derbys. (cf. Magna Oufra (c1100)), Meikle Black Law, Berwickshire, 
Muckle Flugga, Shetland (in this example prob. a partial Anglicization of a Norn name), etc. Cf.:

eOE Bounds (Sawyer 512) in W. de G. Birch Cartularium Saxonicum (1887) II. 520 Pis is para VI sulunga boc æt Miclangrafe. c1275 in W. A. Hulton Coucher Bk. Whalley Abbey (1848) 688, Partem cujusdam terræ..quod vocatur Mikel pughull et Litel pughull. 1379 Rolls of Parl. III. 69/1 Son College appellez Mokel Universite Halle en Oxenford. c1400 Brut (Rawl. B. 171) 50 Aurilambros \& Vter..assemblede a..hoste forto come into michel Britaigne. 1459 Will J. Fastolf in Paston Lett. (1971) I. 90 Castre faste by Mikel Yermuth, in the shire of Norffolk. a1475 in A. Clark Eng. Reg. Godstow Nunnery (1911) I. 287, j other half acre..vppon mochelforlonge...]

A. adj. $\quad$ I. $=$ GREAT a. in various applications. Cf. MUCH a. 1 .

1. a. Great or large in size, bulk, or stature; = MUCH a. 1a.

Also designating a particular place, building, etc. (now only in place names: see etymological note)...

(OED3 s.v. mickle a., pron., n., and adv.)

In the OED3 entry for MALM n., the small-type etymological note discusses possible examples of the use of the element in English place-names. In the list of cognate forms given in the main part of the etymology, reference is made to the use of Old Swedish malm in the place-name Malmo, and to the Shetland place-name Maamy Soond in Fetlar. The placename evidence allows the identification of cognate forms which would otherwise be unknown, and thus enhances our knowledge of the history and development of the word within the Germanic languages: 
malm, $\mathrm{n} .$.

[Cognate with Old Icelandic málmr sand (in the place name Málm-haugar 'sandmounds' (Old Swedish Malmöughe, now Malmö) in Sweden; cf. also the Shetland place name Maamy Soond 'sandy sound' in Fetlar), gold (because found in grains in alluvial deposits: cf. the phrase Rínar raud-málmr 'the red metal of the Rhine'), metal, ore (cf. Old Swedish malmber, Swedish malm, Danish malm ore), Gothic malma sand; also Middle High German malmen to crush (German zermalmen with prefix zer-). Cf. Dutch malen to grind, whirl (> MAELSTROM n.) and verbs in the other main Germanic languages except Old English and Old Frisian from the same Indo-European base; from Indo-European ablaut variants cf. MEAL n. ${ }^{1}$ (and with - $m$ extension also Middle Dutch melm dust, dry sand, Old Saxon melm, Old High German melm dust), and MOULD n. ${ }^{1}$ (with $-m$ extension also Middle Dutch molm, mollem (Dutch molm) mould, German Mulm dust).

Apart from a single probable instance at sense 2, Old English mealm (prob. orig. with basic meaning 'sandy, friable stone') is attested only in the compound MALMSTONE n., the adjective mealmiht sandy, chalky (cf. later MALMY a.), and (unless independently < early Scandinavian) in the place names Malmeton, Lincolnshire (a1066; now Manton), and Malmerby, North Yorkshire (1086; now Melmerby). The word is noted in field names (both as a simplex and as an element in compounds) from southern counties from the 15th cent. onwards (the earliest being Le Malme, Berkshire, 1439) in J. Field Eng. Field Names (1972) 132...]

I. Simple uses.

1. a. A soft friable rock containing a high proportion of chalky material; spec. a greyish-white calcareous sandstone of the Upper Greensand of Surrey and Sussex in 
England (also called firestone). b. A light loamy soil formed by the decomposition of malm rock.

Recorded earliest in MALMSTONE n...

(OED3 s.v. malm n.)

The etymologies of words in OED3 are often more comprehensive and detailed than those of earlier editions (cf. Durkin 1999, Durkin et al. 2002). A growing awareness of the value of toponymic material as an important supplement to lexical material has already increased the volume of scholarly research in this field over the last hundred years, and OED3 endeavours to take account of all relevant etymological scholarship in the course of the revision programme. Place-name evidence is being incorporated in cases where the toponymic material makes a significant contribution to the development of a lexical item. As the revision process continues, there will be many more such additions, and consequently the Germanic toponymicon of the British Isles may be more widely recognised for the wealth of linguistic information it contains. ${ }^{4}$

\footnotetext{
${ }^{1}$ In this paper I will be following the established convention of italicizing historical forms of place-names, and place-names which are 'lost', i.e. no longer in use. Please note that the modern place-names given in passages quoted from OED3 do not follow this convention and are also italicized.

${ }^{2} \mathrm{I}$ am very grateful to $\mathrm{Mr} \mathrm{T}$. A. Hendry for alerting me to the existence of the early form Preueic (a. 1177).

${ }^{3}$ Simon Taylor, personal correspondence.

${ }^{4}$ I am very grateful to Philip Durkin, Carole Hough and Joshua Pendragon for their comments on drafts of this paper.
}

\section{References}

Craigie, W., et al., eds. 1937-2002. The Dictionary of the Older Scottish Tongue. Aberdeen: Aberdeen University Press, Chicago: Chicago University Press, London \& Oxford: Oxford University Press. 
Gelling, Margaret \& Ann Cole. 2001. The Landscape of Place-Names. Stamford: Shaun Tyas.

Grant, W., et al., eds. 1931-76. The Scottish National Dictionary. Edinburgh: Scottish National Dictionary Association.

Dixon, Norman. 1947. The Place-Names of Midlothian. Ph.D. dissertation, University of Edinburgh.

Durkin, Philip. 1999. "Root and branch: revising the etymological component of the OED". Transactions of the Philological Society 97. 1-50.

Durkin, Philip, Anthony Esposito, Neil Fulton, Jane McCauley, Samantha Schad, Tania Styles \& Joanna Tulloch. 2002. "From the etymology workshop: work in progress on the Oxford English Dictionary". Oxford University Working Papers in Linguistics, Philology \& Phonetics 7.225-242.

Fraser, William, ed. 1874. The Lennox. Edinburgh: T. \& A. Constable.

Hough, Carole. 1995. “OE *grǣg in place-names”. Neuphilologische Mitteilungen XCVI/4.361365.

Hough, Carole. 1998. “OE brūn in place-names”. English Studies 79/6.512-521.

Hough, Carole. 1999. “The trumpeters of Bemersyde: a Scottish placename reconsidered”. Names 47.257-68. 
Kitson, Peter. 1997. “Old English Bird-Names (I)”. English Studies 78/6.481-505.

Kitson, Peter. 1998. “Old English Bird-Names (II)”. English Studies 79/1.2-22.

Macdonald, Angus. 1937. The Place-Names of West Lothian. Ph.D. dissertation, University of Edinburgh.

Macdonald, Angus. 1941. The Place-Names of West Lothian. Edinburgh: Oliver \& Boyd.

Nicolaisen, W. F. H. 1976. Scottish Place-Names. London: Batsford. New edn. 2000. Edinburgh: John Donald.

Nicolaisen, W. F. H. 1993. "Scottish place-names as evidence for language change". Names 41.306-313.

Nicolaisen, W. F. H. 1995. "Is there a Northwest Germanic toponymy? Some thoughts and a proposal". Nordwestgermanisch ed. by Edith Marold \& Christiane Zimmermann, 103-14. Berlin: Walter de Gruyter.

Nicolaisen, W. F. H. 2000. Scottish Place-Names. New edn. Edinburgh: John Donald.

Parsons, D. \& T. Styles with C. Hough. 1997. The Vocabulary of English Place-Names: Á-BOX. Nottingham: Centre for English Name Studies. 
Parsons, D. \& T. Styles. 2000. The Vocabulary of English Place-Names: BRACE-CAESTER. Nottingham: Centre for English Name Studies.

Scott, Margaret. 2000. "Privick: A Scottish place-name". Paper presented at the conference of the Society for Name Studies in Britain and Ireland, Bangor, April 2000.

Simpson, John A. \& Edmund Weiner, eds. 1989. $2^{\text {nd }}$ edn. The Oxford English Dictionary. Oxford: Oxford University Press.

Simpson, John A., ed. 2000-. $3^{\text {rd }}$ edn. (in progress) OED Online. Oxford: Oxford University Press.

Smith, A. H., ed. 1956. English Place-Name Elements. Parts I \& II. English Place-Name Survey Vols. 25 \& 26. Cambridge: Cambridge University Press.

Stuart, J., et al. eds. 1878-1908. The Exchequer Rolls of Scotland. Edinburgh: H. M. General Register House.

Taylor, Simon. 2002. "Walking the Marches of Language: Scots in Medieval Boundary Charters". Paper presented at the $45^{\text {th }}$ annual conference of the Scottish Medievalists Society, Pitlochry, January 2002.

Williamson, M. G. 1942. The Non-Celtic Place-Names of the Scottish Border Counties. Ph.D. dissertation, University of Edinburgh.

Wright, Joseph. 1898-1905. The English Dialect Dictionary. London: Henry Frowde. 